\title{
Trade liberalization and ready-made garments industry in Bangladesh
}

\begin{abstract}
The study aims at examining the effect of trade liberalization on ready-made garments (RMG) industry in Bangladesh. It employs Johansen-Juselius Cointegration test and Vector Error Correction Modeling (VECM) on yearly data from January 1990 through September 2011. The results reveal a significant long-term relationship between RMG export of Bangladesh and the three tested explanatory variables (merchandise export of China and India plus domestic inflation in Bangladesh). The Granger Causality test shows the presence of dynamic relationship between the performance of RMG export of Bangladesh and the value of merchandise export from China and India. However, this dynamic relation is nonexistent in relation to the inflation factor.
\end{abstract}

Keyword: New industrial policy; Revised industrial policy; Quantitative restrictions; Structural adjustment program; Multi-fiber agreement; Generalized system of preferences 